\title{
A INFLUÊNCIA DO DIREITO FUNDAMENTAL DA LIBERDADE DE CRENÇA RELIGIOSA DIANTE DO FLUXO IMIGRATÓRIO NO BRASIL - A BUSCA PELO ASILO
}

\section{Jociane Machiavelli Oufella}

Master em Direito, Economia e Política pela Universidade de Pádova - Itália. Especialista em Direito Processual Civil pela Universidade do Contestado. Professora Titular da Graduação e Pós Graduação em Direito da Universidade do Oeste de Santa Catarina, Campus Videira/SC e da Universidade Alto Vale do Rio do Peixe - Campus Caçador/SC. Advogada.

\section{Pricila Carla da Silva Ely}

Especialista em Direito Público pela Escola da Magistratura Federal do Paraná (Esmafe/ Unibrasil), Curitiba/PR. Doutoranda em Ciências Jurídicas pela Pontificia Universidad Catolica da Argentina. Professora da Graduação em Direito da Universidade Alto Vale do Rio do Peixe, Campus Caçador/SC. Advogada.

Recebido em: 21.08.2011

Aprovado em: 02.09.2011

ÁreA do DIREITO: Constitucional

Resumo: 0 tema apresentado corresponde à influência exercida pelo direito fundamental de crença Religiosa, diante do fluxo imigratório no Brasil como busca de asilo. É pressuposto deste trabalho, definir a matéria Imigração, destacando o ingresso do estrangeiro no território nacional, bem como, analisando a situação jurídica deste em território nacional, e descrevendo as modalidades de vistos, previstas no ordenamento jurídico brasileiro. Indica ainda a conceituação da
ABSTRACT: The theme presented corresponds to the influence of the fundamental right of religious belief, given the immigration flow in Brazil as asylum seekers. We assume this work, set the immigration matter, highlighting the entry of the alien in national territory, as well as analyzing the legal situation in this country, and describing the procedures for visas, under Brazilian law. It also shows the concept of matter religion, stressing the inherent characteristics of 
matéria Religião, acentuando as caracteristicas inerentes às três principais religiões monoteistas ocidentais - Judaísmo, Islamismo e Cristianismo. Por fim, o assunto citado aborda a garantia da Liberdade de Crença Religiosa, determinando, primeiramente o conceito de Liberdade; delimitando-a a Liberdade de Crença Religiosa e, ao final, fazendo jus ao direito de crença como pressuposto para garantir o direito de asilo em território brasileiro.

PalavRAS-Chave: Imigração - Liberdade religiosa - Direito de asilo. the three major Western monotheistic religions - Judaism, Islam and Christianity. Finally, the matter said the guarantee covers the Freedom of Religious Belief, determining first the concept of Freedom, delimiting the Freedom of Religious Belief and at the end, be entitled to the right of belief as a precondition to ensure the right of asylum in Brazil.

KEYwoRDS: Immigration - Religious freedom Asylum.

SumÁrIO: 1. Imigração: 1.1 Conceito de imigração; 1.2 Situação jurídica dos estrangeiros; 1.3 Obtenção de vistos: 1.3.1 Visto de trânsito; 1.3.2 Visto de turismo; 1.3.3 Visto temporário; 1.3.4 Visto permanente; 1.3.5 Visto de cortesia; 1.3.6 Visto oficial; 1.3.7 Visto diplomático - 2. Religião: conceito: 2.1 Principais religiões: 2.1.1 Judaismo; 2.1.2 Islamismo; 2.1.3 Cristianismo - 3. 0 direito fundamental da liberdade de crença religiosa: 3.1 Preceito constitucional da liberdade de crença religiosa - 4.0 preceito constitucional da liberdade de crença religiosa diante do fluxo imigratório no Brasil - A busca pelo asilo - 5. Referências bibliográficas.

\section{IMIGRAÇÃO}

\subsection{Conceito de imigração}

O estudo de emigração, imigração e do estrangeiro pertence ao Direito Constitucional Internacional, contudo, o seu desenvolvimento no Direito Internacional Privado é ainda pequeno, tratando-se de assunto regulamentado, quase que exclusivamente pelo direito interno, a não ser que os Estados interessados tenham concluído algum tratado. ${ }^{1}$

Imigração é o movimento de entrada, com ânimo permanente ou temporário e com a intenção de trabalho ou residência, de pessoas de um país para outro. É formada pelos estrangeiros que se dirigem a um Estado com a intenção de nele se estabelecerem, sendo apresentada sob duas formas: individual e coletiva. $^{2}$

1. Mello, Celso Duvivier de Albuquerque. Direito constitucional internacional. 2. ed. Rio de Janeiro: Renovar, 2000. p. 237.

2. Idem, p. 238. 
Estrangeiro é definido, na concepção de Mirtô Fraga, como "todo aquele que não tem nacionalidade do Estado em cujo território se encontra", ${ }^{3}$ bastando, então, para adquirir ou perder a condição de estrangeiro, o deslocamento da jurisdição do Estado a que pertence.

Já para José Afonso da Silva o estrangeiro no Brasil é "(...) quem tenha nascido fora do território nacional que, por qualquer forma prevista na Constituição, não adquira nacionalidade". ${ }^{4}$

O movimento imigratório tem acompanhado desde os primórdios a história da humanidade, sendo responsável, na maioria das vezes, pela modernização e progresso humano. Por outro lado, os fatores políticos, econômicos, sociais e culturais que impulsionaram o deslocamento de pessoas pelo mundo têm se modificado ao longo do tempo, de acordo com a conjuntura predominante na ordem internacional. ${ }^{5}$

Outrossim, já existem projetos relativos a uma nova Lei dos Estrangeiros, que deverá estar em sintonia com os princípios da Constituição Brasileira, da Convenção Internacional da ONU e dos tratados do Mercosul, fazendo parte do programa de Direitos Humanos do atual governo, onde a questão imigratória necessitará ser analisada como um projeto social, econômico, cultural, de direitos humanos, propiciando o intercâmbio social, político e religioso do Brasil com outros povos. ${ }^{6}$

\subsection{Situação jurídica dos estrangeiros}

Em época recente houve dúvidas quanto a se atribuir uma personalidade jurídica à pessoa humana. Na verdade, Estados e Organizações Intergovernamentais não são entidades abstratas e impossíveis de serem individualizadas, como é a pessoa humana. ${ }^{7}$

3. Fraga, Mirtô. O novo Estatuto do Estrangeiro comentado. Rio de Janeiro: Forense, 1985. p. 21.

4. Silva, José Afonso da. Curso de direito constitucional positivo. 28. ed. São Paulo: Malheiros, 2007. p. 335.

5. Chaparro, Verônica Zárate. O estrangeiro à luz do direito internacional e do direito brasileiro. In: Del'Olmo, Florisbal de Souza (coord.). Curso de direito internacional contemporâneo. Rio de Janeiro: Forense, 2003. p. 656.

6. Idem, p. 10-20.

7. Silva, Roberto Luiz. Direito internacional público. 2. ed. Belo Horizonte: Del Rey, 2002. p. 156. 
Por outro lado, o fato de faltar à pessoa humana alguns dos atributos que são enunciados como as cinco categorias fundamentais da personalidade jurídica em Direito Internacional, tão evidentes no que se refere aos Estados (com destaque à impossibilidade de seu acesso a procedimentos judiciais de solução de litígios entre pessoas jurídicas, nomeadamente as arbitragens e a legitimidade ativa ou passiva, por direito próprio a procedimentos frente a Tribunais Judiciários Internacionais) levaram autores renomeados a negarem ter a pessoa humana uma personalidade de Direito Internacional. ${ }^{8}$

Entretanto, antes de aprofundar a referida discussão doutrinária, faz-se necessário estabelecer uma definição da condição jurídica do estrangeiro, que, segundo Irineu Strenger, é "o conjunto de direitos que o estrangeiro goza em determinado país, que não o de sua origem numa certa época, ou seja, o estado de estrangeiro em oposição ao estado de nacional". ${ }^{9}$

É por certo que a posição do homem como sujeito de direito é uma decorrência da orientação jus naturalista adotada para explicar o fundamento do Direito Internacional, pois, duas são as principais razões para o homem ser considerada pessoa internacional: a dignidade humana que leva a ordem jurídica internacional a reconhecer direitos fundamentais e a protegê-los, e a própria noção do direito, obra do homem para o homem. ${ }^{10}$

Sobre a dignidade da pessoa humana comenta Nadia Araújo:

"A proteção da pessoa humana é hoje o objetivo precípuo do ordenamento jurídico e ultrapassa as fronteiras iniciais do direito público, integrando os princípios norteadores do direito constitucional influenciando também na sistemática do Direito Internacional. Assume cada dia mais relevância a interpretação e a utilização dada a questão da proteção da pessoa humana e da sua dignidade, em todas as áreas do Direito, em especial o Internacional Privado."11

A conclusão que se pode chegar é que a melhor posição para o caso é aquela que defende serem sujeitos de Direitos Internacionais os Estados, as Organizações Internacionais e o homem, sendo este último, pessoa internacional como é o Estado, distinguindo-se apenas por ter a sua capacidade jurídica de agir bem mais limitada que a daquele ente. ${ }^{12}$

\footnotetext{
8. Idem, ibidem.

9. Strenger, Irineu. Teoria geral do direito internacional privado. São Paulo: EdUSP, 1973. p. 20.

10. Idem, p. 392.

11. Araújo, Nadia. Direto internacional privado: teoria e prática. 3. ed. Rio de Janeiro: Renovar, 2006. p. 10.

12. Idem, p. 393.
} 
É preciso frisar que apesar das normas de proteção ao estrangeiro constarem em diversas convenções, pactos e protocolos do sistema universal europeu, interamericano e africano dos direitos humanos, sua aplicação pelas instâncias competentes ainda é débil e tênue. Isso se deve por diversos fatores, tais como, o desconhecimento, a ignorância, a xenofobia e a discriminação. ${ }^{13}$

As Constituições brasileiras têm consagrado o princípio de igualdade de direitos entre os estrangeiros e brasileiros, conferindo-lhes as garantias fundamentais da inviolabilidade do direito à vida, à liberdade, à igualdade, à segurança e a propriedade, como o faz o art. $5 .^{\circ}$ da $\mathrm{CF} / 1988 . .^{14}$

Em que pese os argumentos doutrinários ao tema, é de competência privativa da União Federal legislar sobre a Nacionalidade, Cidadania e Naturalização além de Emigração, Imigração, entrada, extradição e expulsão de estrangeiros, nos termos, respectivamente, dos incs. XIII e XV do art. 21 da CF/1988. ${ }^{15}$

O Estatuto do Estrangeiro criado pelo Dec.-lei 941/1969, foi alterado pela Lei 6.964/1981, ${ }^{16}$ que vem regendo, atualmente, os institutos da admissão dos estrangeiros em território nacional, saída, retorno, documentação necessária para viagens e condição de asilado. Além disso, dispõe sobre a naturalização, deportação, expulsão, e extradição, instituindo o Conselho Nacional de Imigração, vinculado ao Ministério da Justiça, Relações Exteriores, Saúde, Agricultura, Indústria e Comércio, que possui representantes do Conselho Nacional de Desenvolvimento Científico e Tecnológico.

\subsection{Obtenção de vistos}

Denomina-se visto a autorização federal concedida a fim de que um estrangeiro ingresse no Brasil. Para a maioria dos países, o visto é emitido apenas no estrangeiro; mas, para alguns, a entrada e a permanência do visitante em território brasileiro é autorizada por um período determinado, definido de acordo com a finalidade da viagem. Assim, são concedidos vistos por motivo

13. Chaparro, Verônica Zárate. Op. cit., p. 656

14. Brasil. Constituição da República Federativa do Brasil. Promulgada em 05.10.1988. Disponível em: [www.planalto.gov.br/ccivil_03/Constituicao/Constitui\%C3\%A7ao. htm]. Acesso em: 17.08.2007. p. 2.

15. BRASIL, 1988, p. 15.

16. BRASIL. Lei 6.964/1981, de 09.12.1981. Altera disposições da Lei 6.815, de 19.08.1980, que define a Situação Jurídica do Estrangeiro no Brasil, cria o Conselho Nacional de Imigração, e dá outras providências. Disponível em: [www.planalto.gov.br/ccivil_03/ Leis/L6964.htm]. Acesso em 14.09.2007. 
de viagens diplomáticas, oficiais, de turismo, visitas, negócios, participação em eventos desportivos e artísticos, além de presença em seminários e conferências internacionais. ${ }^{17}$

O visto configura mera expectativa de direito e segundo o art. 26 da Lei $6.815 / 1980,{ }^{18}$ sua finalidade é comprovar a autenticidade do passaporte, a legalidade e validade dos demais documentos com os quais o estrangeiro pretenda ingressar em outro território.

O estrangeiro que pretenda ingressar no Brasil deverá satisfazer as exigências legais, que variam, sendo mais numerosas quando se trata de imigração, e, menos numerosas se a vinda não tiver âmbito definitivo, sendo que a documentação exigida para sua obtenção pode ser divergente, pois, para turistas originários de certos países, a simples apresentação do passaporte juntamente com a passagem é suficiente. ${ }^{19}$

Desta forma, é notável que nem a Constituição Federal, nem mesmo a legislação atual, ferem os princípios internacionais, pois regulam a matéria ensejando na contribuição de direitos e garantias aos imigrantes, onde é previsto que ao estrangeiro que pretenda entrar no território nacional poderão ser concedidos os vistos seguintes: de trânsito, de turista, temporário, permanente, de cortesia, oficial e, diplomático. ${ }^{20}$

\subsubsection{Visto de trânsito}

O Brasil, por ser um país de dimensões gigantescas, muitas vezes, para se chegar a um país de destino, tenha-se que passar pelo Território Nacional; entretanto, para desembarcar, deverá, o estrangeiro, estar munido do visto de trânsito, conforme definido no art. $8 .^{\circ}$ da Lei $6.815 / 1980,{ }^{21}$ não lhe sendo exigido no caso viagem contínua, que só se interrompa para escalas obrigatórias do meio de transporte utilizado.

17. Pereira, Yepes Bruno. Curso de direito internacional público. 2. ed. São Paulo: Saraiva, 2007. p. 84.

18. Brasil. Lei 6.815/1980. Promulgada em 19.08.1980. Dispõe sobre a situação jurídica do estrangeiro e cria o Conselho Nacional de Imigração. Disponível em: [www. planalto.gov.br/ccivil_03/Leis/L6815.htm]. Acesso em: 17.08.2007.

19. Freitas, Vladimir Passos de. Comentários ao Estatuto do Estrangeiro e opção de nacionalidade. Campinas: Millennium, 2006. p. 76-81.

20. Idem, p. 1 .

21. Art. $8 .^{\circ}$ da Lei 6.815/1980: "O visto de trânsito poderá ser concedido ao estrangeiro que, para atingir o país de destino, tenha de entrar em território nacional”. 
Esta modalidade de visto é concedida a estrangeiros que, durante sua viagem com destino final a um terceiro país, precisam transitar pelo território brasileiro. O visto de trânsito é válido para uma só entrada, cuja estada não possa ultrapassar 10 dias, pois é improrrogável. Se a viagem contínua do estrangeiro tiver de ser interrompida por impossibilidade de transbordo imediato ou por motivo imperioso, o transportador, ou seu agente, dará conhecimento do fato ao Departamento de Polícia Federal, por escrito. Esta, por sua vez, irá autorizar a permanência do estrangeiro durante o período estritamente necessário para proceder com a viagem, sendo que toda e qualquer despesa, proveniente desta situação, deverá ser de responsabilidade da companhia transportadora.

\subsubsection{Visto de turismo}

Entende-se por Turista o estrangeiro que venha para o Brasil, em caráter recreativo ou de visita, sem finalidade imigratória, nem intuito de exercitar atividade remuneratória, podendo-lhe ser concedido visto. A palavra "poderá", expressa no art. 9..$^{\circ}$ do Estatuto do Estrangeiro, ${ }^{22}$ indica discricionariedade, cuja concessão está ligada aos interesses nacionais, assim, a satisfação das exigências da Lei e dos Regulamentos, não assegura ao estrangeiro a obtenção deste visto.

$\mathrm{O}$ visto de turista é conferido às pessoas que desejam entrar no Brasil para turismo ou para visitar amigos ou familiares. A viagem não poderá ser realizada com o propósito de imigração, nem deverá o portador deste tipo de visto, trabalhar ou receber qualquer tipo de remuneração no Brasil. Por exemplo, um estrangeiro vindo ao Brasil em viagem de negócios ou para participar de congresso, deverá solicitar o visto para este propósito. Referido visto possui validade de 5 anos e duração de estada de 90 (noventa) dias, podendo ser prorrogado. ${ }^{23}$

O Brasil pratica a política de reciprocidade quanto aos vistos de turista, isto é, requer visto dos cidadãos de países que, por sua vez, também requerem vistos de cidadãos brasileiros, sendo importante enfatizar que não é incomum a situação de turistas barrados em aeroportos brasileiros por falta de visto.

\subsubsection{Visto temporário}

O visto temporário é concedido àquele que não é turista, e não tenha intuito de estabelecer-se definitivamente no país, porém, venha ao Brasil por um período longo, determinado e com objetivo específico. ${ }^{24}$

22. Brasil, 1980, p. 3.

23. Freitas, Vladimir Passo de. Op. cit., p. 104.

24. Fraga. Op. cit., p. 30. 
Em regra geral este tipo de visto só pode ser obtido, salvo no caso de força maior, na jurisdição consular em que o estrangeiro tenha mantido sua residência pelo prazo mínimo de um ano, dispensados desta exigência os artistas, desportistas, correspondentes de jornal, revistas, rádio, televisão ou de agências noticiosas estrangeiras, por causa da sua contínua e natural movimentação própria de suas profissões. ${ }^{25}$

É o caso, por exemplo, dos estrangeiros que venham em viagem cultural; missões de estudo; viagens de negócios; na condição de artista ou de desportista; na condição de estudante; nas condições de cientista, de professor, de técnico ou profissional de outra categoria, sob regime de contrato ou a serviço do Governo brasileiro; nas condições de correspondente de jornal, de revista, de rádio, de televisão ou de agência noticiosa estrangeira e na condição de ministro de confissão religiosa ou membro de instituto de vida consagrada e de congregação ou ordem religiosa; ressaltando que, estes, devem vir exercer suas funções de ministro. ${ }^{26}$

\subsubsection{Visto permanente}

Esta espécie de visto destina-se ao estrangeiro que pretender fixar-se definitivamente no Brasil; todavia, a política imigratória há de ser ordenada, não podendo caminhar com livre arbítrio, haja vista o caos e a tensão nacional (xenofobia).

Ademais, não pode ter somente regras objetivas e rígidas, havendo de estarem presentes a observação da constituição étnica do povo e a defesa do trabalhador nacional, devendo, a imigração objetivar, primordialmente, proporcionar mão de obra especializada e escassa aos vários setores da economia nacional, visando à Política Nacional de Desenvolvimento (desenvolvimento do homem, da terra e das instituições), em especial, ao aumento da produtividade, à assimilação de tecnologia e à captação de recursos para os setores específicos. ${ }^{27}$

A concessão do visto permanente poderá ficar condicionada, por prazo não superior a cinco anos, ao exercício de atividade certa e à fixação em região determinada do Território Nacional (o que não caracteriza limitação à liberdade individual). A autoridade consular anotará a margem do visto a atividade a ser exercida pelo estrangeiro e a região em que se em que ele fixará seu domicílio.

25. Freitas. Op. cit., p. 104.

26. Idem, ibidem.

27. Fraga, 1985, p. 30. 


\subsubsection{Visto de cortesia}

A Lei não estabelece normas de caráter especial para a concessão, prorrogação ou dispensa do visto de cortesia, conferindo, apenas ao Ministério das Relações Exteriores, por força do art. 19 da Lei 6.815/1980, ${ }^{28}$ a competência para definir, evidentemente através de Portaria do Titular da Pasta, quando será possível concedê-los, prorrogá-los ou dispensá-los, observadas as regras do art. $7 .^{\circ}$ da mesma lei, haja vista serem pressupostos para a concessão de qualquer tipo de visto, sendo, portanto, decidido pelo Ministério das Relações Exteriores.

Sabe-se, no entanto, que na prática é geralmente concedida esta modalidade de visto a empregados domésticos, motoristas, secretários de Ministros, Cônsules e outras autoridades que não dispensam o serviço exclusivo destas pessoas em suas viagens.

\subsubsection{Visto oficial}

Assim como o visto de cortesia, o visto oficial é decidido pelo Ministério das relações Exteriores e é destinado a membros de Organismos Internacionais, como embaixadores, cônsules e outros representantes de Estados Estrangeiros. É preciso informar que apesar de serem cobrados emolumentos consulares para a concessão de vistos, ao visto oficial dispensa-se este encargo, e havendo dúvida quanto à dispensa de visto do titular de passaporte oficial o Departamento de Polícia Federal consultará o Ministério das Relações Exteriores. ${ }^{29}$

\subsubsection{Visto diplomático}

O visto diplomático é concedido para pessoas que venham ao Brasil no intento de missões diplomáticas e consulares, ficando a cargo do Ministro das Relações Exteriores definir quaisquer divergências, concessão e prorrogação deste visto; lembrando que, o fator determinante da concessão desta espécie de visto é o objetivo da viagem e não o tipo de passaporte, cargo ou função de seu titular.

Desta forma, resta demonstrado que os estrangeiros são indivíduos que não possuem a nacionalidade do Estado em que se encontram, contemplando mesmo assim, a personalidade jurídica internacional, sendo que seu ingresso no

28. BRASIL, 1980, p. 3.

29. Idem, p. 4. 
território brasileiro pode se dar de inúmeras formas, mediante a concessão de vistos em relação ao aspecto da visita e a apresentação dos documentos exigidos pela lei nacional.

\section{Religião: CONCEITO}

Historicamente a Religião era considerada como um grupo social, uma identidade comunitária, e que, nos dias atuais, transformou-se em algo individual, próprio, singular, sobretudo naqueles Estados em que o princípio da liberdade de crença constitui uma garantia constitucional fundamental. ${ }^{30}$

A Religião pode ser definida como um conjunto de crenças relacionadas com aquilo que a humanidade considera como sobrenatural, divino e sagrado, bem como, o conjunto de rituais e códigos morais que derivam dessas crenças, sendo que cada religião inspira certas normas e motiva determinadas práticas. ${ }^{31}$

Dentro do que se entende como religião pode-se encontrar muitas crenças e filosofias distintas. As diversas religiões do mundo são de fato muito diferentes entre si. Porém, ainda assim é possível estabelecer uma característica em comum entre todas elas, qual seja, o fato que toda religião possui um sistema de crenças no sobrenatural, geralmente envolvendo divindades ou deuses. ${ }^{32}$

É um triste fato a religião ter sido uma grande fonte de conflitos ao longo dos tempos, e até hoje há comunidades sendo destruídas e sociedades inteiras desestabilizadas em consequência do ódio e do fanatismo religioso. Não é à toa que muitos questionam o papel da religião na sociedade humana. ${ }^{33}$

Leonardo Boff, ao discorrer sobre o tema religião menciona:

"Julgo que religião esteja relacionada com a crença no direito à salvação pregada por qualquer tradição de fé, crença esta que tem como um de seus principais aspectos a aceitação de alguma forma de realidade metafísica ou sobrenatural, incluindo possivelmente uma ideia de paraíso ou nirvana, sendo as religiões fonte de ética, isto é, de comportamentos." ${ }^{34}$

30. Campos, Maria da Conceição Oliveira. O princípio das nacionalidades nas relações internacionais. Belo Horizonte: Del Rey, 2003. p. 140.

31. Nova Enciclopédia Barsa. Livro do ano 2001. São Paulo: Barsa Consultoria Editoral Ltda., 2001. vol. 12, p. 276.

32. Idem, ibidem.

33. Lama, Dalai. Uma ética para o novo milênio. Trad. Maria Luiza Newlands. Rio de Janeiro: Sextante, 2000. p. 236.

34. Boff, Leonardo. Espiritualidade: um caminho de transformação. Rio de Janeiro: Sextante, 2001. p. 20. 
Dalai Lama ${ }^{35}$ afirma que, em seu modo de pensar, a diversidade existente entre as várias tradições religiosas é extremamente enriquecedora, uma vez que a cultura religiosa influencia significativamente no modo de vida das pessoas, guiando-as através de costumes e dogmas próprios de cada crença.

Atualmente, segundo o jurista Jacob Dolinger, ${ }^{36}$ a religião constitui um dos elementos de conexão usados entre diversos países, como os asiáticos e africanos, onde perdura a competência original dos tribunais eclesiásticos e a aplicação das leis religiosas para as questões inseridas no estatuto e na capacidade das pessoas.

Em que pese as narrativas supracitadas, um conceito de religião requer muito mais do que simples palavras, outrossim, engloba inúmeros fatores culturais, ensinamentos e dogmas que variam em proporções distintas entre cada indivíduo. Assim, merece especial destaque a tese de que as pessoas são seres únicos, individualizados, e, portanto, cada um atribui significado divergente ao tema religião.

\subsection{Principais religiões}

A explosão mundial de novas seitas constitui um grande desafio para as religiões e igrejas tradicionais. Os novos movimentos religiosos, por seu dinamismo proselista e suas propostas alternativas, provocam as mais diversas rejeições. Todavia, Urbano Zilles ${ }^{37}$ menciona que três são as grandes religiões da humanidade caracterizadas pelo monoteísmo, quais sejam, o Judaísmo, o Cristianismo e Islamismo.

Estas três religiões, apesar de compreenderem um universo distinto de dogmas e crenças, professam a fé em um único Deus e não admitem outros deuses a seu lado, sendo todas religiões proféticas, onde a mais antiga é o Judaísmo. ${ }^{38}$

Primeiramente é notório destacar que o Brasil é um país laico (que não possui religião oficial), contudo, nota-se a influência marcante do Cristianismo, até mesmo nos feriados nacionais, embora desde proclamação da República em 1890, o Estado tenha sido expressamente separado da Igreja. ${ }^{39}$

\footnotetext{
35. Lama, Dalai. Op. cit., p. 244.

36. Dolinger, Jacob. Op. cit., p. 200.

37. Zilles, Urbano. Religiões, crenças e crendices. Porto Alegre: EDIPUCRS, 1997. p. 7.

38. Idem, p. 61.

39. BACH, Marcus. As grandes religiões do mundo. 2. ed. Rio de Janeiro: Record - Nova Era, 2002. p. 248.
} 
Inerente as controvérsias religiosas no Brasil e na França, Emerson Giumbelli afirma que o processo de laicização do Estado, implica em um conjunto de arranjos jurídicos diversos, estabelece as condições do pacto da separação entre a esfera estatal e religiosa, mas no mesmo ato estabelece uma relação umbilical ente Estado e religião. Em nenhum momento ou lugar, as religiões deixaram de ser uma questão de Estado. ${ }^{40}$

Ao apontar estas considerações, passa-se a pormenorizar as três principais religiões mundiais, com foco na garantia de liberdade religiosa, objeto do presente estudo.

\subsubsection{Judaísmo}

A entrada do judaísmo no complexo da história sagrada foi altamente dramática. Os cinco primeiros livros de Moisés, a Torá, contam a história do povo judeu, uma saga que está intimamente ligada à do antigo reino de Israel, embora não seja seu sinônimo. ${ }^{41}$

A linhagem do Judaísmo remota ao patriarca Abraão e a importância da Aliança (o acordo de Deus com o povo escolhido de Israel) e da Lei (o registro escrito da revelação de Deus) não são um exagero dentro dessa expressão de fé. ${ }^{42}$

Na tradição judaica a Lei é a Torá, ou seja, os cinco ensinamentos de Moisés. Eles representam o registro escrito da revelação de Deus que, segunda a crença, esteve ativo em todos os aspectos do desenvolvimento e história humanos, continuando assim até hoje, sendo reforçada e mantida pela inspiração dos profetas, que, de acordo com a Escritura, eram algumas pessoas escolhidas por Deus para lembrar o amor do Criador pelo povo e a necessidade da obediência a Lei. ${ }^{43}$

A religião judaica tinha na lei sagrada os assentamentos de igualdade: eram iguais os homens crentes, estando excluídos, portanto, os infiéis, as mulheres e os escravos. ${ }^{44}$

40. Giumbelli, Emerson. O fim da religião: dilemas da liberdade religiosa no Brasil e na França. São Paulo: Attar, 2002. p. 326.

41. BACH, Marcus. Op. cit., p. 81.

42. Toropov, Brandon. O guia completo das religiões do mundo. Trad. Martha Malvezzi Leal. São Paulo: Madras, 2006. p. 75.

43. Idem, p. 71.

44. Goldfarb, José Luiz; Judensnaider, Ivy. Os judeus e o Islã. Revista História Viva - Grandes Religiões 2, n. 2, p. 40-45. São Paulo: Duetto, 2007. 
O religioso judeu reza três vezes por dia. Todo o sétimo dia é o Sabbath, um dia de descanso, adoração a Deus, estudo e prece. Num certo sentido, todo o culto judaico reconhece Deus como o governante e o proprietário de tudo que os seres humanos têm e usam. ${ }^{45}$

Em outras palavras, o Judaísmo sustenta uma forma de prática religiosa baseada na comunidade e em costumes sociais característicos (como a circuncisão entre os homens) que reforçam esse sentimento de pertencer a um grupo e o objetivo clássico do culto judaico é o de entender toda a vida como uma liturgia (um ritual público). ${ }^{46}$

A língua sagrada do judaísmo é o hebraico e os principais feriados judaicos incluem o Rosh Hashaná (Ano novo judaico), o Iom Kipur (Dia do perdão) e a Pesach (Páscoa Judaica). ${ }^{47}$

Como uma nova forma de expressão religiosa, atualmente privilegia-se a horizontalidade em detrimento da verticalidade. No lugar de cultos sacrifícios feitos por sacerdotes, há pessoas reunidas para ler, contar suas próprias histórias e partilhar experiências religiosas, absorvendo o fato de que o Deus universal não está mais preso a um espaço geográfico para ser lembrado. ${ }^{48}$

\subsubsection{Islamismo}

A palavra árabe Islam significa submissão e é derivada de uma palavra que significa paz. Num contesto religioso, denota total submissão à vontade de Deus e tem origem semelhante ao Cristianismo, pois ambos possuem como patriarca Abraão. ${ }^{49}$

De acordo com os ensinamentos de Urbano Zilles:

"O islamismo é a religião do Corão ou Alcorão, livro revelado por Deus a Maomé. Ele sentiu - se chamado a pregar sua revelação em Meca, sua cidade natal, onde encontrou fortes obstáculos. A herança política - religiosa de Maomé foi recolhida pelos califs. Toda a vida religiosa da comunidade islâmica gira em torno do Corão. Ele é a base da educação tradicional do islamismo. O

\footnotetext{
45. ВАС̆, Marcus. Op. cit., p. 86-87.

46. Idem, p. 87.

47. Toropov, Brandon. Op. cit.

48. Leone, Alexandre. A era dos profetas. Revista História Viva 2, n. 2, p. 28-31. São Paulo: Duetto, 2007. Grandes Religiões.

49. HaYek, Samir El. Compreenda o Islam e os Muçulmanos. São Bernardo do Campo: Junta de Assistência Social Islâmica Brasileira, 2005. p. 6.
} 
islamismo é, antes de tudo, um projeto religioso que faz de todo o homem um 'testemunho de Deus'. Este projeto está ameaçado pelos problemas econômi$\cos$ - sociais, pela secularização e politização da fé." 50

Os muçulmanos acreditam que o Corão é a verdadeira e inspirada palavra de Deus, transmitida ao profeta Maomé pelo anjo Gabriel. Eles asseguram que entre os muitos escritos sagrados que existem no mundo, só o Corão nunca foi revestido ou alterado..$^{51}$

Segundo Samir El Hayek:

O Islã não é uma religião nova. Ela é a mesma verdade que Deus revelou por intermédio de Seus profetas para toda a humanidade. Para um quinto da população mundial, o Islam é uma religião e um sistema de vida completa. Os muçulmanos seguem uma religião de paz, misericórdia, perdão, e a maioria nada tem a ver com os eventos extremamente graves que vieram a se juntar a sua fé..$^{52}$

Os muçulmanos crêem em um Único e incomparável Deus; nos anjos criados por Ele; nos profetas por intermédio dos quais suas revelações foram trazidas para a humanidade; no Dia do Juízo; na apresentação de conta individual pelas ações praticadas; na autoridade total de Deus sobre o destino do homem e na vida após a morte. ${ }^{53}$

Os cinco pilares que compõe o Islã, ou seja, a estrutura da vida do muçulmano é baseada na fé (iman), na oração (salat), no interesse pelo necessitado (zakat), no jejum (syam) e na peregrinação à Meca (hajj) para quem tiver posses para tal. ${ }^{54}$

O Alcorão, livro sagrado no Islamismo, é o registro das palavras exatas revelados por Deus por intermédio do Anjo Gabriel ao profeta Mohammad, sendo a principal fonte de fé e da prática de todo o muçulmano, proporcionando orientação para uma sociedade justa, uma conduta humana decente e um equitativo sistema econômico. ${ }^{55}$

Em sede de mandamentos relativos ao Alcorão, Samir El Hayek ${ }^{56}$ comenta que estes ensinamentos protegem inclusive os templos dos não muçulmanos,

50. Zilles, Urbano. Op. cit., p. 72.

51. Idem, p. 129.

52. HaYek, Samir. Op. cit., p. 4.

53. Idem, ibidem.

54. Idem, p. 11.

55. Idem, ibidem.

56. Idem, p. 20. 
pois, já em 634, quando o Califa Ômar entrou em Jerusalém, garantiu liberdade de culto a todas as comunidades religiosas da cidade.

Dentre as razões da rápida e pacífica difusão do Islã está a simplicidade de sua doutrina, uma vez, que convoca para a crença no Deus Único, merecedor de adoração, e instrui o homem a usar seus poderes de inteligência e observação. ${ }^{57}$

A família é a base da sociedade islâmica. A paz e a segurança proporcionadas por uma unidade familiar estável é muito valorizada e vista como essencial para o desenvolvimento espiritual de seus membros, sendo a mulher considerada uma pessoa com o seu próprio direito, inclusive de posses e o uso do nome de solteira ainda que casada. ${ }^{58}$

No Estado islâmico, a personalidade do indivíduo é de grande importância. Ela não é absorvida pelo Estado, e sim, evolui-se juntamente com este. É ela que lhe dá apoio, trabalhando em prol da sua perpetuação e aprimoramento da personalidade deste.

Quanto aos direitos humanos, o islã também os garante de algumas formas. Assim, a liberdade de consciência é declarada no próprio ordenamento religioso, bem como, a vida e a propriedade de todo cidadão, num país islâmico, são consideradas sagradas, quer a pessoa seja muçulmana ou não. O racismo, por sua vez, é incompreensível, uma vez que a estrutura religiosa é regida pela igualdade humana. ${ }^{59}$

O privilégio da liberdade do credo proporcionado pela jurisprudência islâmica alcançou um patamar que, acredita-se não ter paralelo com qualquer outro sistema legal, além do islâmico. O Islã não força o ser humano a trocar sua fé para aceitá-lo, não deixando de convidá-lo a fazer isso. Mas, o chamado do Islã é uma coisa, e a sua aceitação compulsória é outra, sendo o primeiro lícito e o segundo ilícito. ${ }^{60}$

Porquanto, a igualdade é um princípio destacado na lei islâmica, um requisito de justiça, aplicando-se a lei a todos sem distinção de quem quer que seja, e sem discriminação dos indivíduos quer pelo sexo, pela cor, riqueza, parentesco, quer mesmo pela crença, ou quaisquer outros motivos pelos quais as pessoas queiram se distinguir uma das outras. ${ }^{61}$

\footnotetext{
57. Idem, p. 9.

58. Idem, ibidem.

59. Idem, p. 32.

60. Zaidan, Abdul Karim. O indivíduo e o Estado no islam. São Bernardo: Junta de Assistência Social Islâmica Brasileira, 1990. p. 92.

61. Idem, p. 32.
} 


\subsubsection{Cristianismo}

O Cristianismo é um termo utilizado de modo genérico para caracterizar a religião fundada por Jesus Cristo, onde se designam cristãos aqueles que a professam. Em termos de história das religiões, o Cristianismo é um desenvolvimento do Judaísmo, porém, diferencia-se deste último pelo reconhecimento de um novo profeta, superior a Moisés, qual seja, Jesus de Nazaré. ${ }^{62}$

A figura centro do Cristianismo, Jesus, foi objeto de mistério e veneração por séculos e pronunciamentos a seu respeito devem ser tratados com ceticismo. O nome Jesus é uma forma latinizada do grego "Iesous", uma transliteração de um nome hebraico Y'shua, e Cristo, não é propriamente um nome, e sim, uma qualidade, descrição, que significa ungido. Assim, na tradição judaica, seria uma figura escolhida e ungida que traria a salvação para Israel. ${ }^{63}$

O nome de Jesus Cristo encerra um momento decisivo (e à época controverso) na história da Igreja. Em outras palavras, a figura no centro dessa expressão de fé é descrita a distância, em traduções, como o resultado das influências culturais gregas sobre as sociedades mediterrâneas, nos quais ela alcançou pela primeira vez ampla aceitação entre os não judeus. Foi depois desta fase de seu desenvolvimento que o Cristianismo começou a ascensão que o levaria ao status de uma das maiores religiões do mundo. ${ }^{64}$

Uma das razões para ser cauteloso com o uso de instrumentos lógicos para descrever o Cristianismo é que ele não é (para muitos fiéis) um sistema fechado, concluído. Os cristãos, ao viver a sua fé, não olham para trás, para um período histórico específico, mas para a frente, rumo à redenção e ressurreição mediante Jesus, por isso mesmo são lembrados de que sua fé é uma direção, não um conjunto estático de princípios. ${ }^{65}$

De um ponto de origem único, as revoluções religiosas europeias do século $\mathrm{XVI}$, as religiões designadas como Protestantes formaram a mais diversa corrente das três divisões dentro do Cristianismo. A variedade pode ser mais do que um pouco intimidadora porque a coleção de visões protestantes apresenta uma rica profusão de tradições baseadas na Bíblia. ${ }^{66}$

62. Zilles, Urbano. Op. cit., p. 70.

63. Toropov, Brandon. Op. cit., p. 105.

64. Idem, p. 109.

65. Idem, p. 111.

66. Idem, p. 127. 
Dentre as inúmeras Igrejas Cristãs cita-se: Igreja Anglicana; Igreja Metodista; Igrejas Batistas; Congregacionalismo; Fundamentalismo; Pentecostalismo; e alguns Movimentos protestantes distintos: Quacres ou amigos; Associação Universalista Unitária; Movimento Ciência Cristã; Adventistas do Sétimo dia; Testemunhas de Jeová e a Igreja de Jesus Cristo dos Santos Últimos Dias (Mormos). ${ }^{67}$

Desta forma procurou-se retratar as principais religiões monoteístas existentes, lembrando que atualmente a diversidade religiosa alcançou níveis tão distintos que é humanamente impossível discorrer sobre todas as religiões existentes, mesmo que haja um traço em comum entre elas (como a crença em um único Deus).

\section{0 DiREITO FUNDAMENTAL DA LIBERDADE DE CRENÇA RELIGIOSA}

O princípio fundamental da liberdade, garantido no ordenamento jurídico brasileiro, exprime a faculdade de se fazer ou não o que se quer; de pensar como se entende; de ir e vir a qualquer atividade; tudo conforme a livre determinação da pessoa, quando não haja regra proibitiva para a prática do ato ou não se institua princípio restritivo ao exercício da atividade. ${ }^{68}$

Cecília Meireles, em Romanceiro da Inconfidência, comenta a complexidade do tema: "(...) Liberdade, essa palavra que o sonho humano alimenta que não há ninguém que explique e ninguém que não entenda (...)". ${ }^{69}$

Para Howard Caygill ${ }^{70}$ o tema liberdade tem duas qualidades significativas e afins, as quais envolvem a liberdade como independência de qualquer forma de dependência e o poder do sujeito legislar para si.

Charles de Secondat Baron de Montesquieu, ao reportar-se a liberdade, narra que "não há palavra que tenha recebido mais significados diferentes, e que tenha impressionado os espíritos de tantas maneiras", ${ }^{71}$ e desta forma afirma que a liberdade se distingui da independência, posto que, esta deve consistir

67. Idem, ibidem.

68. Silva, José Afonso da. Op. cit., p. 490.

69. Meireles, Cecília. Romanceiro da Inconfidência. 10. ed. Rio de Janeiro: Nova Fronteira, 2005. p. 140.

70. Caygill, Howard. Dicionário Kant. Trad. Álvaro Cabral. Rio de Janeiro: Jorge Zahar, 2000. p. 216.

71. Montesquieu. Charles de Socondat Baron de. O espírito das leis. 5. ed. São Paulo: Saraiva, 1998. p. 12. 
em poder fazer o que se deve querer e em não ser obrigado a fazer o que não se deve querer.

No Direito Constitucional, as liberdades públicas, ou simplesmente liberdades, expressam os direitos liberais, que são aqueles direitos fundamentais (também chamados direitos humanos ou individuais) a garantir o indivíduo da imiscuição na sua personalidade pelo Estado ou pelos demais integrantes da sociedade; através das liberdades, pretende-se reservar à pessoa uma área de atuação imune à intervenção do poder. ${ }^{72}$

O jurista Rui Barbosa entendia a liberdade como um valor básico de seu ideário, tanto que, são suas as palavras:

"Mas acima da pátria ainda há alguma coisa: a liberdade; porque a liberdade é a condição da vida da pátria, é a consciência, é o homem, é o principio divino do nosso existir, e o único bem cujo sacrifício a Pátria não nos pode reclamar." 73

A liberdade está inserida nos direitos de primeira geração, ou seja, os primeiros a constarem do instrumento normativo constitucional, a saber, os direitos civis e políticos, que em grande parte correspondem, por um prisma histórico, àquela fase inaugural do constitucionalismo do Ocidente. ${ }^{74}$

Nesse diapasão, Ingo Wolfgang Sarlet prescreve:

“(...) são apresentados como direitos de cunho 'negativo', uma vez que dirigidos a uma abstenção, e não a uma conduta positiva por parte dos poderes públicos, sendo, nesse sentido, 'direitos de resistência ou de oposição perante o Estado'. Assumem particularmente relevo no rol desses direitos, especialmente pela sua notória inspiração jusnaturalista, os direitos à vida, à liberdade, à propriedade e à igualdade perante a lei. São, posteriormente, complementados por um leque de liberdades."75

Consoante com os argumentos destacados é compreensível que muitas vezes o homem necessita lutar para ter os seus direitos reconhecidos, eis que o simples texto legal carece de aplicabilidade, ou, eficácia material, contudo,

72. Silva, José Afonso da. Op. cit., p. 490.

73. Barbosa, Rui. Secularização dos Cemitérios. In: Obras Completas de Rui Barbosa. Rio de Janeiro: Ministério da Educação, 1950. vol. 7, t. 1, p. 163.

74. Bonavides, Paulo. Curso de direito constitucional. 11. ed. São Paulo: Malheiros, 2001. p. 517.

75. Sarlet, Ingo Wolfgang. A eficácia dos direitos fundamentais. 3. ed. Porto Alegre: Livraria do Advogado, 2003. p. 51. 
ainda é recente esse leque de direito pautados na Constituição Federal, razão porque, há muito ainda que se escrever e ser cobrado em termos de liberdade.

\subsection{Preceito constitucional da liberdade de crença religiosa}

Desde os primórdios de sua história, as sociedades humanas estão diretamente atreladas a alguma religião e no mundo moderno, a religião se dissociou do governo, mas não perdeu sua importância para a sociedade.

É sabido que o conceito de liberdade varia conforme a região e o momento histórico, contudo, a liberdade mais evocada certamente é a religiosa, pois, nos mais díspares lugares do mundo existem manifestação de algum credo, dentro de padrões morais e dos bons costumes que não firam os estatutos legais. ${ }^{76}$

$\mathrm{O}$ direito à liberdade religiosa, uma das espécies do gênero direito fundamental à liberdade, consiste na possibilidade de livre escolha pelo indivíduo da sua orientação religiosa, porém, não se esgota no plano da crença individual, meramente subjetiva, de foro íntimo, e sim, abarca a prática religiosa, também denominada de liberdade de culto. ${ }^{77}$

Celso Ribeiro Bastos ${ }^{78}$ entende que o princípio da liberdade religiosa decorre da liberdade de pensamento e desta forma assevera que em função de que a religião possui duas dimensões (uma espiritual e outra externa) e, portanto, demanda um aparato de garantia, deve necessariamente englobar a parte ritualística e solene, ou seja, a liberdade de culto.

A liberdade de culto consiste na liberdade de orar e praticar os atos próprios das manifestações exteriores em casa ou em público, bem como recebimento de contribuições para tanto. ${ }^{79}$

Por sua vez, a liberdade de organização religiosa tem uma dimensão muito importante no seu relacionamento com o Estado, porquanto, três modelos são possíveis, quais sejam, a fusão, a união e a separação. O Brasil enquadra-se inequivocadamente neste último desde o advento da República, com a edição do Dec. 119-A, de 17.01.1890, que instaurou a separação entre a Igreja e o Estado. ${ }^{80}$

76. Tavares, André Ramos. Curso de direito constitucional. 2. ed. São Paulo: Saraiva, 2003. p. 426.

77. Cretella. José Júnior. Comentários à Constituição de 1988. Rio de Janeiro: Forense Universitária, 1997. vol. I, p. 218.

78. Bastos, Celso Ribeiro. Dicionário de direito constitucional. São Paulo: Saraiva, 1994. p. 104.

79. Silva, José Afonso da. Op. cit., p. 221.

80. Idem, p. 191. 
O princípio fundamental da liberdade de organização religiosa, segundo Celso Ribeiro Bastos, é o da não colocação de dificuldades e embaraços a criação de igrejas, mencionando ainda que às pessoas de direito público não são permitidas a criação destas ou de cultos religiosos. ${ }^{81}$

A conquista constitucional da liberdade religiosa é a verdadeira consagração da maturidade de um povo, pois é ela é o verdadeiro desdobramento da liberdade de pensamento e manifestação. A abrangência do preceito constitucional é ampla, e sendo a religião o complexo de princípios que dirigem os pensamentos, ações e adoração do homem para com Deus, acaba por compreender a crença, o dogma, a moral, a liturgia e o culto. O constrangimento à pessoa humana, de forma a renunciar sua fé, representa o desrespeito às diversidades democráticas de ideias, filosóficas e a própria diversidade espiritual. ${ }^{82}$

Por ser o Brasil um Estado laico, nenhuma religião pode exercer pressão ideológica junto aos cidadãos livres, nem imprimir sua marca ou papéis do Estado, porque não há verdadeira democracia sem liberdade religiosa, isto é, sem igualdade dos cidadãos perante a lei, também no domínio das crenças religiosas. A Constituição Federal, malgrado haver assegurado a liberdade de crença, estabeleceu que tal direito individual não pode ser invocado para a isenção de obrigação legal a todos imposta e a recusa de cumprir prestação alternativa prevista em lei. ${ }^{83}$

A Declaração sobre a Eliminação de Todas as Formas de Intolerância e de Discriminação baseada em Religião ou Crença ${ }^{84}$ motivou a importância do seu texto considerando que a religião ou crença, para quem a professa, constitui um dos elementos fundamentais de sua concepção de vida e que, portanto a liberdade de religião ou crença deve ser integralmente respeitada e garantida. Ademais, é essencial promover a compreensão, a tolerância e o respeito das questões relacionadas com a liberdade de religião e crença, assegurando que não se aceita o uso da religião ou crença com fins incompatíveis aos princípios constitucionais. ${ }^{85}$

81. Bastos, Celso Ribeiro. Op. cit., p. 191.

82. MoraEs, Alexandre de. Direitos humanos fundamentais. 4. ed. São Paulo: Atlas, 2002. p. 190.

83. TRF-5. ${ }^{a}$ Reg., 3. ${ }^{a}$ Vara Federal, Proc. 2004.115-4/SE, j. 24.03.2004, rel. Juiz Edmilson da Silva Pimenta. Disponível em: [www.jfse.gov.br/sentencas/constitucionais/ const2004/sentconstedmilson20040001154.htm]. Acesso em: 06.09.2006.

84. BRASIL, 1980, p. 4.

85. Alves, José Augusto Lindgren. A arquitetura internacional dos direitos humanos. São Paulo: FTD, 1997. p. 202. 
Fábio Konder Comparato, comenta acerca da liberdade individual e da liberdade política:

"A experiência veio, porém, demonstrar a intima ligação entre essas duas dimensões da liberdade. A liberdade política sem as liberdades individuais não passa de engodo demagógico de Estados autoritários ou totalitários. E as liberdades individuais, sem efetiva participação política do povo no governo, mal escondem a dominação oligárquica dos mais ricos." 86

O constitucionalista José Joaquim Gomes Canotilho ${ }^{87}$ esclarece que a quebra de unidade religiosa da cristandade deu origem à aparição de minorias religiosas que defendiam o direito de cada um à verdadeira fé. Esta defesa da liberdade religiosa postulava, pelo menos, a ideia de tolerância religiosa e a proibição do Estado em impor ao foro íntimo do crente uma religião oficial.

Prescreve ainda que alguns autores vão mesmo ao ponto de ver na luta pela liberdade de religião a verdadeira origem dos direitos fundamentais. Parece, porém, que se tratava mais da ideia de tolerância religiosa para credos diferentes do que propriamente da concepção da liberdade de religião e crença, como direito inalienável do homem, tal como veio a ser proclamado nos modernos documentos constitucionais. ${ }^{88}$

Desde o ordenamento da República (Dec. 119-A, de 17.01.1890) existe separação entre o Estado e a Igreja, sendo o Brasil um país leigo, laico ou não confessional, não existindo, portanto, qualquer religião oficial. ${ }^{89}$

A liberdade religiosa veio assegurada, basicamente, pelo art. 5. ${ }^{\circ}, \mathrm{VI}$, da CF/1988, que dispõe acerca da inviolabilidade da liberdade de crença e garante o exercício dos cultos religiosos e a proteção aos locais de culto e as suas liturgias; no entanto, completam o arcabouço constitucional de proteção de liberdade de crença os incs. VII e VIII do mesmo art. 5. ${ }^{\circ}$, o art. 19, I, art. 150, VI, $b$ e o art. $210, \S 1 .^{\circ}$, todos da CF/1988. ${ }^{90}$

86. Comparato, Fábio Konder. A afirmação histórica dos direitos humanos. 5. ed. São Paulo: Saraiva, 2007. p. 64.

87. Canotilho, José Joaquim Gomes. Direito constitucional e teoria da Constituição. 7. ed. Portugal: Almedina, 2006. p. 383.

88. Idem, ibidem.

89. BRASIL. Dec. 119-A, de 07.01.1890. Proíbe a intervenção da autoridade federal e dos Estados federados em matéria religiosa, consagra a plena liberdade de cultos, extingue o padroado e estabelece outras providências. Disponível em: [www.planalto.gov. br/ccivil_03/decreto/1851-1899/D119-A.htm]. Acesso em: 14.09.2007.

90. Brasil, 1988, p. 85. 
Do conjunto de dispositivos indicados depura-se que a liberdade de religião carrega em seu interior alguns elementos conceituais, que definem o seu regime jurídico, com base nos seguintes pontos: Liberdade de fé e de confissão religiosa; Direito ao exercício de qualquer religião (liberdade de culto); Liberdade de associação religiosa; Dever de neutralidade do Estado - que não só deve possuir caráter laico como também não pode favorecer, financiar ou embaraçar o exercício de qualquer religião e Ensino religioso de caráter facultativo. ${ }^{91}$

O Brasil, como um Estado Democrático de Direito, que possui como fundamento a dignidade da pessoa humana, deve se ater para que a liberdade de crença seja exercida concomitantemente com o pleno exercício da cidadania, pois, o reconhecimento da cidadania em um sistema político está na razão direta da sua capacidade de garantir às pessoas o direito à liberdade. ${ }^{92}$

Em face da Constituição Federal é válido o ensinamento de Aldir Guedes Soriano ${ }^{93}$ de que o Estado tem o dever de proteger o pluralismo religioso dentro de seu território, criar as condições materiais para um bom exercício sem problemas dos atos religiosos das distintas religiões, velar pela pureza do princípio de igualdade religiosa, mas, deve manter-se à margem do fato religioso, sem incorporá-lo em sua ideologia.

\section{O PRECEITO CONSTITUCIONAL DA LIBERDADE DE CRENÇA RELIGIOSA DIANTE DO FLUXO IMIGRATÓRIO NO BRASIL - A BUSCA PELO ASILO}

A Declaração Universal dos Direitos Humanos de 1948 prescreve em seu art. XIV que toda pessoa vítima de perseguição tem o direito de procurar e receber asilo em outros países. Referido direito não pode ser invocado em caso de perseguição legitimamente motivada por crimes de direito comum ou por atos contrários aos propósitos ou princípios das Nações Unidas. ${ }^{94}$

O direito de asilo objetiva amparar o indivíduo vítima de perseguição, abrangendo duas espécies o asilo territorial (externo) e o asilo diplomático (interno). A concessão de asilo é ato discricionário dos Estados Soberanos, não há aplicabilidade do princípio da reciprocidade, a Convenção Interamericana

91. Idem, p. 101.

92. Alves, José Augusto Lindgren. Op. cit., p. 202.

93. Soriano, Aldir Guedes O direito à liberdade religiosa. Jornal Correio Braziliense, Cad. Direito \& Justiça, 08.11.2004, p. 2.

94. Neves, Gustavo Bregalda. Direito internacional público e direito internacional privado. 2. ed. São Paulo: Atlas, 2008. p. 88. 
sobre Asilo Territorial, realizada em Caracas em 1954, dispões que todo Estado tem direito, no exercício de sua soberania, de admitir dentro de seu território as pessoas que julgar conveniente. ${ }^{95}$

$\mathrm{O}$ asilo político trata do acolhimento de estrangeiro perseguido por causa de dissidência política, delitos de opinião, ou por crimes que, relacionados com a segurança do Estado, não configuram quebra do direito penal comum. Por sua vez, o asilo diplomático é uma forma provisória do asilo político, só praticada regularmente na América Latina, nunca sendo diplomático de forma definitiva, significando um estágio provisório para o asilo territorial. ${ }^{96}$

Note-se que o direito ao asilo está intimamente ligado ao direito de liberdade de crença religiosa, pois o estrangeiro buscará um Estado que o aceite e que lhe permita professar a sua crença. Historicamente, o direito de liberdade de crença religiosa no Brasil sofreu grandes restrições e perseguições, principalmente no que concerne à liberdade de culto, pois, as constituições brasileiras trataram do tema liberdade de crença religiosa deixando um campo aberto para o cotidiano jurídico julgar que por esse tema compreendia-se apenas a liberdade de crença e não a de culto. Desta forma, mesmo quando a liberdade de culto se fazia oficialmente presente, utilizava-se como argumentos a garantia da ordem pública, da moralidade e defesa urbana contra a poluição sonora, para camuflar a garantia do culto religioso. ${ }^{97}$

É cediço que durante grande parte dos séculos a liberdade religiosa, quando aceita, foi tomada na acepção de liberdade de crença e não de culto. Exemplar neste sentido foi a Constituição do Império de $1824,{ }^{98}$ onde o Estado, de feições religiosas, ligado oficialmente à Igreja Católica Apostólica Romana, permitia a liberdade de crença, embora não admitisse a de culto, servindo de obstáculo à visualização explícita da diferença e da perseguição em matéria de religião.

A Constituição Política do Império do Brasil ${ }^{99}$ proclamava no art. $5 .^{\circ}$ que a Religião Católica Apostólica Romana continuaria sendo a religião do Império e

95. Idem, ibidem.

96. Rezek, José Francisco. Direito internacional público: curso elementar. 12. ed. São Paulo: Saraiva, 2010. p. 222.

97. Ribeiro, Milton. Liberdade religiosa: uma proposta para debate. São Paulo: Mackenzie, 2002. p. 40.

98. Idem, p. 41.

99. Brasil. Constituição Política do Império do Brasil. Outorgada em 25.03.2005. Disponível em: [www.planalto.gov.br/ccivil_03/Constituicao/Constituiçao24.htm]. Acesso em: 27.08.2007. 
que todas as outras Religiões seriam permitidas, desde que atendidos os requisitos de culto doméstico ou particular, em casas para isso destinadas, sem forma alguma exterior do templo. Assim sendo, não excluiu a liberdade religiosa da teoria, porém, tornou-a ineficaz na prática.

A Constituição Republicana de $1891,{ }^{100}$ inspirada no Positivismo e no racionalismo em voga na época, dá a questão religiosa outro enfoque: baseada no Dec. 119-A, de 07.01.1890, que cindiu a Igreja do Estado, a primeira Constituição Republicana, no art. 72, parágrafo 3, garante a liberdade de crença, de culto e de associação.

Por sua vez, a Constituição Brasileira de $1967,{ }^{101}$ na época do regime militar, ressalva, ao lado da liberdade de crença e de culto, a possibilidade de perda dos direitos incompatíveis com a escusa de consciência. Sendo permitido ao Estado, por motivo de questões políticas, interferir na liberdade religiosa.

A atual Constituição Federal ${ }^{102}$ traz à baila o tópico da liberdade religiosa como garantia individual de brasileiros e estrangeiros, amplamente difundida no ordenamento jurídico, inclusive com proteção aos locais de culto e imunidade tributária das igrejas.

Vale lembrar que, atinente aos imigrantes, desde o período imperial o impulso publicitário difundido no exterior era o de que, aos imigrantes que se estabelecessem no Brasil seria garantido além de terras e algumas imunidades de tributos, o direito de conservarem as suas culturas e cultuarem os seus deuses de acordo com as suas crenças e dogmas.

Contemporaneamente o mundo presencia inúmeros conflitos ligados direta ou indiretamente à religião, motivo pelo qual, pessoas consideradas leigas atribuem certos fatos, geradores destes conflitos, a determinadas religiões e

100. BRasil. Constituição da República dos Estados Unidos do Brasil. Promulgada em: 24.02.1891. Disponível em: [www.planalto.gov.br/ccivil_03/Constituicao/Constituiçao24.htm]. Acesso em: 27.08.2007, p. 6.

101. BRASIL. Constituição da República Federativa do Brasil. Promulgada em 20.10.1967. Disponível em: [www.planalto.gov.br/ccivil_03/Constituicao/Constituiçao67.htm]. Acesso em: 27.08.2007, p. 5.

102. "Art. 5. ${ }^{\circ}$ Todos são iguais perante a lei, sem distinção de qualquer natureza, garantindo-se aos brasileiros e aos estrangeiros residentes no País a inviolabilidade do direito à vida, à liberdade, à igualdade, à segurança e à propriedade, nos termos seguintes: (...)

VI - é inviolável a liberdade de consciência e de crença, sendo assegurado o livre exercício dos cultos religiosos e garantida, na forma da lei, a proteção aos locais de culto e a suas liturgias." 
consequentemente, causam uma impressão negativa destas, contribuindo para a propagação de restrições sociais quanto aos direitos conquistados em sede de liberdade religiosa.

Exemplificando o discurso acima citam-se acontecimentos como as Guerras Santas envolvendo a faixa de Gaza (Irã, Palestina, Israel); atentados contra os Estados Unidos da América; ataques premeditados na cidade de Madri; e outros tantos que convergem na acepção do senso comum de que as religiões são responsáveis por tais acontecimentos, esquecendo-se que estes conflitos são gerados, na maioria das vezes, por fatores econômico englobando recursos como petróleo, e que utilizam a religião como escudo, a fim de não deixar transparecer literalmente o patamar em que chegou a ganância humana, capaz de matar semelhantes unicamente por motivos financeiros. ${ }^{103}$

Esta contradição social em exigir do Estado a manutenção da liberdade de crença religiosa e ostentar repúdio a alguns rituais, dogmas ou características próprias de algumas religiões, torna, na prática, impróprio esta garantia, o que resulta em um retrocesso quanto à aquisição de liberdades individuais. ${ }^{104}$

No entanto, é valiosa a concepção de que a Constituição Federal representa, em um Estado Democrático de Direito, muito mais do que um simples ordenamento jurídico, e sim, o embasamento para quaisquer criações legais ou aderência a legislação estrangeira.

Neste norte, destaca-se que este mesmo diploma legal preocupou-se em definir em seu próprio texto que esta garantia, de liberdade de crença, constitui cláusula pétrea, ou seja, cláusula inalterável por legislações complementares, ordinárias ou outra forma que não seja um novo poder constituinte. ${ }^{105}$

Ao estrangeiro, como visto anteriormente, é assegurado um rol de direitos individuais inerentes aos brasileiros natos, e com isso, a divulgação internacional destas garantias constitui um atrativo àqueles que sofrem perseguições por motivos religiosos, ou, não podem exercer livremente o culto aos seus deuses, bem como, encontram-se tolhidos quanto à manifestação de suas convicções filosóficas.

Não são raros acontecimentos a níveis globais onde estrangeiros são impedidos de exerceram com livre-arbítrio a defesa de suas manifestações

103. ReIs, Henrique Marcelo dos. Relações econômicas internacionais e direitos humanos. São Paulo: Quartier Latin, 2005. p. 39-89.

104. Bıcudo, Hélio. Direitos humanos e sua proteção. São Paulo: FTD, 1997. p. 12-17.

105. BRASIL, 1988, p. 44. 
religiosas, tendo que, na maioria das vezes, agirem obscuramente no intento de manter a cultura e os costumes dos rituais acessíveis aos seus descendentes. ${ }^{106}$

Felizmente no Brasil de hoje a realidade está projetada no sentido de atender a demanda de estrangeiros aceitando os seus costumes, crenças e dogmas, da forma original com que elas se apresentam; até mesmo chegando-se a incorporar algumas mudanças na própria sociedade, e de modo fundamental, respeitando admiravelmente as diferenças culturais.

É assim que a arquitetura de normas instituída pela a Constituição Cidadã, apesar de carecer em muitos aspectos de preceitos complementares a fim de contribuir para uma força executiva destes direitos, vem se destacando socialmente com reverência ao texto constitucional, acatando as disposições impostas com o objetivo de assegurar o cumprimento desta garantia.

A formação social brasileira, pautada na miscigenação de raças e costumes, precisa ser conduzida no sentido de adaptar as diversidades culturais com o fito de resguardar os direitos individuais e coletivos garantidos aos nacionais e aos imigrantes.

Nesta linha de pensamento a liberdade religiosa aparece como tema de alta complexidade e relevância, pois, o mundo moderno elegeu a legalidade e o direito como modos de organização da vida social e de estruturação das relações individuais e sociais. ${ }^{107}$

Desta forma, é notório que, mesmo a duras penas, conseguiu-se inserir no texto constitucional uma das garantias natas de todo o ser humano, qual seja o direito de professar sua crença, bem como, o direito de não professar fé alguma; e mais, além de estar expresso no ápice do ordenamento jurídico nacional, a sociedade vem desenvolvendo-se no sentido de aceitar e cobrar medidas de proteção a esse direito.

É, contudo, imperativo que não se perca esta conquista, que foi fruto do impacto sobre a consciência da humanidade de abomináveis excessos ocorridos durante a história brasileira, e no mais, a humanidade caminha na busca de melhores condições de vida e dignidade, assimilando a importância das garantias adquiridas e integrando socialmente todas as pessoas com suas diferenças e peculiaridades.

106. Bicudo, Hélio. Op. cit., p. 18-29.

107. Ribeiro, Milton. Op. cit., p. 9. 


\section{REFERÊNCIAS BIBLIOGRÁFICAS}

Alves, José Augusto Lindgren. A arquitetura internacional dos direitos humanos. São Paulo: FTD, 1997.

Araujo, Luiz Alberto David; Nunes Junior, Vidal Serrano. Curso de Direito Constitucional. 6. ed. São Paulo: Saraiva, 2002.

Araujo, Nadia de. Direto internacional privado: teoria e prática. 3. ed. Rio de Janeiro: Renovar, 2006.

BACH, Marcus. As grandes religiões do mundo. 2. ed. Rio de Janeiro: Record, 2002.

Barbosa, Rui. Secularização dos Cemitérios. Obras Completas de Rui Barbosa. Rio de Janeiro: Ministério da Educação, 1950. vol. 7, t. 1.

Bastos, Celso Ribeiro. Dicionário de direito constitucional. São Paulo: Saraiva, 1994.

Bicudo, Hélio. Direitos humanos e sua proteção. São Paulo: FTD, 1997.

Boff, Leonardo. Espiritualidade: um caminho de transformação. Rio de Janeiro: Sextante, 2001.

Bonavides, Paulo. Curso de direito constitucional. 11. ed. São Paulo: Malheiros, 2001.

Brasil. Constituição de 1824. Constituição Política do Império do Brasil. Outorgada em 25.03.1824. Disponível em [www.planalto.gov.br/ccivil_03/Constituicao/Constituiçao24.htm].

Constituição de 1891. Constituição da República dos Estados Unidos do Brasil. Promulgada em 24.02.1891. Disponível em [www.planalto.gov.br/ ccivil_03/Constituicao/Constituiçao24.htm].

Constituição de 1967. Constituição da República Federativa do Brasil. Promulgada em 20.10.1967. Disponível em [www.planalto.gov.br/ccivil_03/ Constituicao/Constituiçao67.htm].

Constituição de 1988. Constituição da República Federativa do Brasil. Promulgada em 05.10.1988. Disponível em [www.planalto.gov.br/ccivil_03/ Constituicao/Constitui\%C3\%A7ao.htm].

Dec. 119-A, de 07.01.1890. Disponível em [www.planalto.gov.br/ccivil_03/decreto/1851-1899/D119-A.htm].

Dec. 5.647, de 08.01.1929. Disponível em [www2.mre.gov.br/dai/estrangeiros.htm].

Lei 6.815/1980. Promulgada em 19.08.1980. Disponível em [www.planalto.gov.br/ccivil_03/Leis/L6815.htm].

. Lei 6.964/1981, de 09.12.1981. Disponível em [www.planalto.gov.br/ ccivil_03/Leis/L6964.htm].

Caygill, Howard. Dicionário Kant. Trad. Álvaro Cabral. Rio de Janeiro: Jorge Zahar, 2000.

CAmpos, Maria da Conceição Oliveira. O princípio das nacionalidades nas relações internacionais. Belo Horizonte: Del Rey, 2003. 
Canotilho, José Joaquim Gomes. Direito constitucional e teoria da Constituição. 7. ed. Coimbra: Almedina, 2006.

Carvalho, Kildare. Direito constitucional. 11. ed. Belo Horizonte: Del Rey, 2005.

Comparato, Fábio Konder. A afirmação histórica dos direitos humanos. 5. ed. São Paulo: Saraiva, 2007.

Cretella, José Júnior. Comentários à Constituição de 1988. Rio de Janeiro: Forense Universitária, 1997. vol. I.

Dé'Omo, Florisbal de Souza (coord.). Curso de direito internacional contemporâneo. Rio de Janeiro: Forense, 2003.

Dolinger, Jacob. Direito internacional privado: parte geral. 6. ed. São Paulo: Renovar, 2001.

Nova Enciclopédia Barsa. Livro do ano 2001. São Paulo: Barsa, 2001. vol. 12.

Fraga, Mirtô. O novo Estatuto do Estrangeiro comentado. Rio de Janeiro: Forense, 1985.

Freitas, Vladimir Passos de. Comentários ao Estatuto do Estrangeiro e opção de nacionalidade. Campinas: Millennium, 2006.

Giumbelli, Emerson. O fim da religião: dilemas da liberdade religiosa no Brasil e na França. São Paulo: Attar, 2002.

Guimarães, Deocleciano Torrieri. Dicionário técnico jurídico. 5. ed. São Paulo: Rideel, 2003.

Hayek, Samir El. Compreenda o Islam e os muçulmanos. São Paulo: Federação das Associações Muçulmanas do Brasil, 2005.

Lama, Dalai. Uma ética para o novo milênio. Trad. Maria Luiza Newlands. Rio de Janeiro: Sextante, 2000.

Leone, Alexandre. A era dos profetas. Revista História Viva. vol. 2. São Paulo: Duetto, 2007. Grandes Religiões.

Meireles, Cecília. Romanceiro da inconfidência. 10. ed. Rio de Janeiro: Nova Fronteira, 2005.

Mello, Celso Duvivier de Albuquerque. Direito constitucional internacional. 2. ed. Rio de Janeiro: Renovar, 2000.

Montesquieu, Charles de Socondat Baron de. O espírito das leis. 5. ed. São Paulo: Saraiva, 1998.

Moraes, Alexandre de. Direitos humanos fundamentais. 4. ed. São Paulo: Atlas, 2002.

Neves, Gustavo Bregalda. Direito internacional público e direito internacional privado. 2. ed. São Paulo: Atlas, 2008.

Pereira, Yepes Bruno. Curso de direito internacional público. 2. ed. São Paulo: Saraiva, 2007.

ReIs, Henrique Marcelo dos. Relações econômicas internacionais e direitos humanos. São Paulo: Quartier Latin, 2005. 
Rezek, José Francisco. Direito internacional público. 12. ed. São Paulo: Saraiva, 2010.

SARLET, Ingo Wolfgang. A eficácia dos direitos fundamentais. 3. ed. Porto Alegre: Livraria do Advogado, 2003.

SiLva, José Afonso da. Curso de direito constitucional positivo. 28. ed. São Paulo: Malheiros, 2007.

Silva, Roberto Luiz. Direito internacional público. 2. ed. Belo Horizonte: Del Rey, 2002.

Soriano, Aldir Guedes. O direito à liberdade religiosa. Jornal Correio Braziliense, Cad. Direito \& Justiça, 08.11.2004.

Strenger, Irineu. Teoria geral do direito internacional privado. São Paulo: Ed.USP, 1973.

Tavares, André Ramos. Curso de direito constitucional. 2. ed. São Paulo: Saraiva, 2003.

Toropov, Brandon. O guia completo das religiões do mundo. Trad. Martha Malvezzi Leal. São Paulo: Madras, 2006.

Zaidan, Abdul Karim. O indivíduo e o Estado no islam. São Bernardo: Junta de Assistência Social Islâmica Brasileira, 1990.

Zilles, Urbano. Religiões, crenças e crendices. Porto Alegre: EDIPUCRS, 1997.

\section{Pesouisas do Editorial}

\section{Veja também Doutrina}

- Anti-semitismo, tolerância e valores: anotações sobre o papel do judiciário e a questão da intolerância a partir do voto do Ministro Celso de Mello no HC 82.424, de Alexandre Gustavo Melo Franco Bahia - RT847/443;

- Da proteção à liberdade de religião ou crença no direito consitucional e internacional, de Lourdes Sima Santos - RDCl 51/120;

- Direitos individuais e direitos das minorias nacionais: uma crítica à política de "suplementação" dos direitos humanos em contextos multiculturais, de Marcelo de Araujo - $R D C / 55 / 89$;

- Inmigración/xenofobia ante las instituciones culturales y religiosas, de Antonio Beristain - RBCCrim 49/317; e

- Liberdade religiosa e direitos humanos: a polêmica sobre o véu islâmico, de Claudia de Miranda Avena - RDCl 72/356. 